\title{
PENGARUH PENGGUNAAN METODE PEMBELAJARAN TWO STAY TWO STRAY DAN NUMBERED HEADS TOGETHER DISERTAI TUTOR SEBAYA PADA MATERI TERMOKIMIA TERHADAP PRESTASI DENGAN MEMPERHATIKAN KEMAMPUAN MATEMATIS SISWA KELAS XI IPA DI SMA NEGERI 3 BOYOLALI TAHUN AJARAN 2015/2016
}

\author{
Ery Fendy Yuliansyah, Suryadi Budi Utomo* dan Ashadi \\ Program Studi Pendidikan Kimia, FKIP,Universitas Sebelas Maret, Surakarta, Indonesia \\ *Keperluan korespondensi, telp: 081548781644, email: sbukim98@yahoo.com
}

\begin{abstract}
ABSTRAK
Penelitian ini bertujuan untuk mengetahui: (1) pengaruh pembelajaran Numbered Heads Together (NHT) dimodifikasi Tutor Sebaya dan Two Stay Two Stray (TSTS) terhadap prestasi belajar siswa pada materi pokok Termokimia; (2) pengaruh kemampuan matematis terhadap prestasi belajar siswa pada materi pokok Termokimia; dan (3) interaksi antara pembelajaran NHT dimodifikasi Tutor Sebaya dan TSTS dengan kemampuan matematis terhadap prestasi belajar siswa pada materi pokok Termokimia. Penelitian ini menggunakan metode eksperimen dengan desain faktorial $2 \times 2$. Subjek penelitian adalah siswa kelas XI IPA 2 dan XI IPA 5 SMA Negeri 3 Boyolali tahun pelajaran 2015/2016 yang diambil dengan teknik cluster random sampling. Hasil penelitian menunjukkan bahwa: (1) Terdapat pengaruh pembelajaran NHT disertai Tutor Sebaya dan TSTS terhadap prestasi belajar kognitif, tetapi tidak terdapat pengaruh pembelajaran terhadap prestasi belajar ranah afektif dan psikomotor pada materi pokok Termokimia. Berdasarkan rata-rata nilai prestasi belajar ranah kognitif, siswa yang menerim pembelajaran NHT disertai Tutor Sebaya $(70,13)$ menghasilkan prestasi belajar kognitif yang lebih baik daripada siswa yang menerima pembelajaran TSTS $(63,75)$; (2) Tidak terdapat pengaruh kemampuan matematis tinggi dan rendah terhadap prestasi belajar ranah kognitif, afektif, dan psikomotor pada materi pokok Termokimia; dan (3) Terdapat interaksi pembelajaran NHT disertai Tutor Sebaya dan TSTS dengan kemampuan matematis terhadap prestasi belajar afektif pada materi pokok Termokimia. tetapi tidak terdapat interaksi pembelajaran NHT disertai Tutor Sebaya dan TSTS dengan kemampuan matematis terhadap prestasi belajar ranah kognitif dan psikomotor pada materi pokok Termokimia.
\end{abstract}

Kata Kunci: NHT, TSTS, tutor sebaya, kemampuan matematis, prestasi belajar.

\section{PENDAHULUAN}

Kurikulum diartikan sebagai sejumlah kegiatan yang diberikan kepada siswa. Kegiatan itu sebagian besar adalah menyajikan bahan pelajaran agar siswa menerima, menguasai dan mengembangkan bahan pelajaran itu [1]. Berdasarkan putusan Peraturan Menteri Pendidikan dan Kebudayaan Republik Indonesia Nomor 160 tahun 2014 tentang Pemberlakuan Kurikulum Tahun 2006 dan Kurikulum
2013 disebutkan dalam Pasal 1 bahwa satuan pendidikan dasar dan pendidikan menengah yang melaksanakan Kurikulum 2013 sejak semester pertama tahun 2014/2015 kembali melaksanakan Kurikulum Tahun 2006 mulai semester kedua tahun 2014/2015 sampai ada ketetapan kementerian untuk melaksanakan Kurikulum 2013. Dalam pasal 2 ayat 1 disebutkan bahwa satuan pendidikan dasar dan satuan pendidikan menengah yang telah melakukan Kurikulum 2013 selama tiga semester 
tetap melaksanakan Kurikulum 2013. Sedangkan dalam pasal 4 Permendikbud RI No 160 tahun 2014 disebutkan bahwa satuan pendidikan yang melaksanakan KTSP hanya diperbolehkan menerapkan KTSP paling lama hingga tahun ajaran 2019/2020. Pemberlakuan kedua kurikulum ini diharapkan dapat memperbaiki proses belajar sehingga dapat meningkatkan prestasi belajar peserta didik. Dengan meningkatnya prestasi belajar peserta didik maka kualitas pendidikan akan semakin baik. [2].

Dengan adanya keputusan tersebut kurikulum pendidikan yang saat ini sedang diterapkan oleh SMA $\mathrm{N} 3$ Boyolali adalah Kurikulum Tingkat Satuan Pendidikan (KTSP) sebagai pengembangan dari kurikulum 2004. Prinsip yang digunakan dalam pengembangan KTSP berpusat pada potensi, perkembangan, kebutuhan, dan kepentingan peserta didik serta lingkungannya. Pada KTSP ini, guru diberi kesempatan untuk mengembangkan indikator pembelajarannya sendiri sehingga guru dituntut untuk kreatif dalam memilih serta mengembangkan materi pembelajaran yang akan disampaikan di sekolah. Pengembangan KTSP jenjang pendidikan dasar dan menengah mengacu pada Standar Nasional Pendidikan, Kerangka Dasar dan Struktur Kurikulum. Pedoman implementasi kurikulum KTSP dikembangkan oleh satuan pendidikan dengan melibatkan komite sekolah/madrasah, dan kemudian disahkan oleh kepala dinas pendidikan atau kantor kementerian agama provinsi dan kabupaten/kota sesuai dengan kewenangannya [3].

Berbagai metode pembelajaran telah banyak ditemukan dan dikembangkan oleh para ahli, namun sebuah metode yang cocok untuk jenis pembelajaran tertentu, belum tentu cocok untuk jenis pembelajaran lain. Hal ini disebabkan karena tujuan belajar, karakteristik siswa, materi belajar serta lingkungan belajar yang beragam dan bervariasi. Dengan penggunaan metode yang berbeda diharapkan dapat mendeteksi metode manakah yang paling sesuai jika diterapkan pada materi tertentu. Salah satu model pembelajaran yang bisa diterapkan dalam materi Termokimia adalah model pembelajaran kooperatif. Menurut Johson, dkk (1998) dalam Huda 2011 menjelaskan bahwa model pembelajaran kooperatif merupakan salah satu model pembelajaran yang selalu disarankan oleh hampir semua peneliti pedagogis. TSTS dan NHT juga merupakan contoh metode pembelajaran dari model pembelajaran kooperatif [4].

Metode two stay two stray adalah salah satu metode pembelajaran kooperatif yang dapat meningkatkan aktivitas siswa dan menciptakan suasana belajar yang menyenangkan. Model pembelajaran ini memberikan kesempatan kepada anggota kelompok untuk membagikan hasil atau informasi ke anggota kelompok lain. Dengan model pembelajaran ini siswa saling bertukar informasi, siswa memiliki peran dan tanggung jawab untuk mempelajari bahan diskusi bersama kelompok ketika menjadi 'tamu' maupun 'tuan rumah'. Dengan demikian, pengetahuan dan wawasan siswa berkembang, siswa lebih menguasai topik diskusi sehingga hasil belajar siswa dapat ditingkatkan.

Sedangkan Metode NHT adalah salah satu pengembangan dari metode Team Games Tournament (TGT). Penggunaan metode NHT memberikan waktu yang lebih banyak kepada siswa untuk berdiskusi di dalam kelompoknya, siswa dapat saling bertukar pikiran satu sama lain. Pembelajaran menggunakan NHT lebih memiliki keaktifan dalam mencari hal yang belum dipahami, salah satunya ketika siswa menuliskan jawaban hasil kerjasama kelompoknya, akan terdapat beberapa siswa yang akan bertanya-tanya penyebab jawaban mereka berbeda. Faktor sensorik berperan sebagai kecemasan yang akan menimbulkan motivasi memiliki efek yang penting dalam pencapaian prestasi akademik, dan juga merupakan komponen penting dari proses pendidikan dan pembelajaran.

Materi pokok Termokimia merupakan salah satu materi kimia yang bersifat hitungan dan membutuhkan pemahaman konsep yang kuat sehingga sering dianggap sulit bagi siswa. 
Berdasarkan hasil wawancara dengan beberapa siswa dan guru kimia di SMA N 3 Boyolali, diketahui bahwa materi termokimia merupakan salah satu materi pokok kimia yang masih dianggap sulit dipahami terkait dalam penyelesaian soal-soalnya yang membutuhkan banyak pemahaman konsep serta keterampilan dalam mengoperasikan angka-angkanya. Ini menyebabkan pelajaran termokimia kurang menarik bagi siswa. Berdasarkan daftar nilai mata pelajaran kimia tahun ajaran 2014/2015. Dapat diketahui bahwa persentase ketuntasan siswa untuk materi termokimia pada tahun ajaran 2014/2015 hanya sekitar $39 \%$ dari 32 siswa dalam satu kelas, dan $61 \%$ lainnya masih di bawah KKM.

Menurut Manurung dkk [5] Model pembelajaran kooperatif NHT memberikan pengaruh prestasi belajar kognitif yang lebih baik daripada model pembelajaran kooperatif LT pada materi tata nama senyawa kimia. Depaz dan Moni [6] membuktikan bahwa metode tutor teman sebaya mampu membantu siswa menyelesaikan tugas dan kuis. Sanubari, Yamtina dan Rejeki [7] juga membuktikan bahwa tutor sebaya dapat meningkatkan minat dan prestasi belajar siswa. Hasil penelitian Fitriyah, Purwantoyo, Chasnah [8] menunjukkan diketahui bahwa aktivitas siswa selama proses pembelajaran dengan menggunakan model kooperatif two stay two stray menunjukkan kriteria baik.

Setelah mengkaji karakteristik materi, metode pembelajaran yang tepat, serta berbagai aspek kemampuan matematis yang dibutuhkan, maka maka akan dilakukan penelitian mengenai pengaruh penggunaan metode pembelajaran two stay two stray dan numbered heads together dengan modifikasi tutor sebaya pada materi termokimia terhadap prestasi dengan memperhatikan kemampuan matematis siswa kelas XI IPA di SMA NEGERI 3 Boyolali Tahun ajaran 2015/2016.

\section{METODE PENELITIAN}

Penelitian ini menggunakan metode eksperimen dengan desain faktorial $2 \times 2$. Untuk lebih jelasnya, rancangan penelitian dapat dilihat pada Tabel 1.

Tabel 1. Rancangan Penelitian Desain Faktorial $2 \times 2$

\begin{tabular}{lcc}
\hline \multirow{1}{*}{$\begin{array}{c}\text { Model } \\
\text { Pembelajaran }(\mathrm{A})\end{array}$} & \multicolumn{2}{c}{ Kemampuan } \\
\cline { 2 - 3 } & $\begin{array}{c}\text { Matematis }(\mathrm{B}) \\
\left(\mathrm{B}_{1}\right)\end{array}$ & $\begin{array}{c}\text { Rendah } \\
\left(\mathrm{B}_{2}\right)\end{array}$ \\
\hline $\begin{array}{l}\text { NHT dengan } \\
\text { modifikasi Tutor }\end{array}$ & $\mathrm{A}_{1} \mathrm{~B}_{1}$ & $\mathrm{~A}_{1} \mathrm{~B}_{2}$ \\
$\begin{array}{l}\text { Sebaya } \\
\text { TSTS }\end{array}$ & $\mathrm{A}_{2} \mathrm{~B}_{1}$ & $\mathrm{~A}_{2} \mathrm{~B}_{2}$ \\
\hline
\end{tabular}

Keterangan:

$\mathrm{A}_{1} \mathrm{~B}_{1}=$ Prestasi kelompok siswa yang menggunakan metode pembelajaran NHT dengan modifikasi tutor sebaya dengan kemampuan Matematis tinggi.

$\mathrm{A}_{1} \mathrm{~B}_{2}=$ Prestasi kelompok siswa yang menggunakan metode pembelajaran $N H T$ dengan modifikasi tutor sebaya dengan kemampuan Matematis rendah.

$\mathrm{A}_{2} \mathrm{~B}_{1}=$ Prestasi kelompok siswa yang menggunakan metode pembelajaran TSTS dengan kemampuan Matematis tinggi.

$\mathrm{A}_{2} \mathrm{~B}_{2}=$ Prestasi kelompok siswa yang menggunakan metode pembelajaran TSTS dengan kemampuan Matematis rendah.

Penelitian ini dilakukan di SMA Negeri 3 Boyolali. Populasi dalam penelitian ini adalah siswa kelas XI IPA SMA Negeri 3 Boyolali tahun pelajaran 2015/2016. Pengambilan sampel dilakukan secara cluster random sampling. Sampel yang terpilih adalah siswa kelas XI IPA 5 sebagai kelas eksperimen I yang diberi perlakuan metode $N H T$ dengan modifikasi tutor Sebaya dan XI IPA 2 sebagai kelas eksperimen II yang diberi perlakuan metode TSTS.

Teknik pengumpulan data menggunakan: (1) dokumentasi nilai ulangan tengah semester gasal kelas XI IPA SMA Negeri 3 Boyolali tahun pelajaran 2015/2016; (2) instrumen tes untuk mengukur kemampuan Matematis [9] dan prestasi kognitif; (3) angket untuk mengukur prestasi afektif; (4) observasi untuk mengukur prestasi afektif dan psikomotor.

Teknik analisis data terdiri dari uji prasyarat analisis dan uji hipotesis. Uji prasyarat analisis meliputi uji normalitas 
dan uji homogenitas. Uji hipotesis menggunakan uji ANAVA. Analisis dilakukan dengan bantuan software IBM SPSS version 22.

Instrumen yang digunakan dalam penelitian ini dibedakan menjadi dua yaitu instrumen pembelajaran dan instrumen penilaian. Instrumen pembelajaran terdiri dari silabus, RPP. Sedangkan instrumen penilaian terdiri dari instrumen penilaian kognitif, afektif dan psikomotor. Teknik analisis instrumen pembelajaran menggunakan uji validitas isi dengan formula Gregory. Dari hasil analisis diperoleh nilai CV silabus dan RPP pembelajaran berturutturut $(1,00)$, dan $(0,86)$. Teknik analisis instrumen kognitif menggu-nakan uji validitas isi diperoleh nilai CV sebesar 0,96 dan uji reliabilitas menggunakan rumus KR-20 diperoleh nilai sebesar 0,72 . Selain itu, instrumen penilaian kognitif juga diuji tingkat kesukaran soal dan daya pembedanya menggunakan software ITEMAN. Setelah dilakukan analisis terhadap hasil uji coba instrumen penilaian kognitif diperoleh kesimpulan bahwa dari 25 soal yang diuji cobakan, 3 soal tergolong sukar, 14 soal tergolong sedang, dan 8 soal tergolong mudah. Dari 25 soal tersebut, juga disimpulkan bahwa daya pembeda 9 soal tergolong baik, 12 soal tergolong cukup, 1 soal tergolong jelek, dan 3 soal tergolong jelek sekali.

Teknik analisis angket afektif dan penilaian observasi menggunakan uji validitas isi, diperoleh nilai CV untuk angket penilaian diri dan lembar observasi berturut-turut sebesar 1,00 dan 1,00. Uji reliabilitas menggunakan rumus Alpha. Hasil uji coba reliabilitas angket penilaian diri 0,82.

Teknik analisis penilaian observasi psikomotor menggunakan uji validitas isi, diperoleh nilai CV sebesar 1,00. Instrumen tes kemampuan Matematis juga diuji validitasnya dengan hasil CV sebesar 1,00 dan reliabilitas sebesar 0,88.

\section{HASIL DAN PEMBAHASAN}

Data yang diperoleh adalah data prestasi belajar siswa meliputi ranah kognitif, afektif, dan psikomotor serta data kemampuan Matematis siswa. Data tersebut dirangkum dalam Tabel 2 .

Tabel 2. Rangkuman Deskripsi Data Penelitian

\begin{tabular}{lcc}
\hline \multirow{2}{*}{$\begin{array}{c}\text { Jenis } \\
\text { Penilaian }\end{array}$} & \multicolumn{2}{c}{ Nilai Rata-rata } \\
\cline { 2 - 3 } & $\begin{array}{c}\text { NHT dengan } \\
\text { Modifikasi } \\
\text { tutor Sebaya }\end{array}$ & TSTS \\
\hline Kognitif & 70,12 & 63,75 \\
Afektif & 72,00 & 73,00 \\
Psikomotor & 84,00 & 85,00 \\
Kemampuan & 82,60 & 86,20 \\
Matematis & 82,60 \\
\hline
\end{tabular}

Pada tahap awal, dilakukan analisis terhadap kondisi awal siswa. Analisis ini didasarkan atas nilai $\mathrm{UH}$ Hidrokarbon. Kedua kelas diuji normalitas, homogenitas dan kesamaan ratarata. Dari uji normalitas menggunakan Shapiro-Wilk diperoleh hasil bahwa kedua kelas berdistribusi normal. Dari uji homogenitas menggunakan Levene statistic diperoleh hasil bahwa kedua kelas homogen. Sedangkan dari uji kesamaan rata-rata diperolah hasil bahwa kedua kelas tidak memiliki perbedaan rata-rata nilai UH Hidrokarbon (kemampuan awal setara).

Sebelum diberi perlakuan metode pembelajaran NHT dengan modifikasi Tutor Sebaya (kelas eksperimen I) dan TSTS (kelas eksperimen II) kedua kelas menerima tes kemampuan Matematis untuk mengelompokkan siswa pada kategori tinggi atau rendah. Adapun data mengenai jumlah siswa yang memiliki kemampuan Matematis kategori tinggi dan rendah dirangkum dalam Tabel 3.

Sebelum dilakukan uji hipotesis dilakukan uji persyaratan analisis meliputi uji normalitas dan uji homogenitas. Data hasil uji norma-litasnya dirangkum dalam Tabel 4. Sedangkan hasil uji homogenitasnya dirangkum dalam Tabel 5. Setelah dilakukan uji persyaratan analisis, selanjutnya pengujian hipotesis menggunakan uji statistik parametrik Two-Way ANOVA dan nonparametrik menggunakan uji Kruskal Wallis. Hasil uji untuk prestasi belajar kognitif, afektif, dan 
psikomotor secara berturut-turut dirangkum pada Tabel 6, 7, dan 8.

Pada hipotesis pertama, hasil pengujian anava dua jalan ranah kognitif untuk mengetahui model pembelajaran yang diterapkan dengan media berbeda menunjukkan bahwa nilai Sig. $(0,002)<$ a $(0,05)$, maka $\mathrm{H}_{0 \mathrm{~A}}$ ditolak dan $\mathrm{H}_{1 \mathrm{~A}}$ diterima. Dapat disimpulkan bahwa terdapat pengaruh metode pembelajaran NHT disertai Tutor Sebaya dan TSTS terhadap prestasi belajar Kognitif siswa pada materi pokok Termokimia. Sedangkan pada ranah afektif menunjukkan bahwa nilai Sig. $(0,963)>\alpha(0,05)$, dan pada ranah psikomotor nilai Asymp. Sig. $(0,945)>\alpha(0,05)$ sehingga $\mathrm{H}_{0}$ diterima. Dapat disimpulkan bahwa tidak terdapat pengaruh metode pembelajaran terhadap prestasi belajar afektif dan psikomotor pada materi pokok Termokimia.

Tabel 3. Jumlah Siswa yang Memiliki Kemampuan Matematis Tinggi dan Rendah

\begin{tabular}{ccccc}
\hline \multirow{2}{*}{$\begin{array}{c}\text { Kemampuan } \\
\text { Matematis }\end{array}$} & \multicolumn{2}{c}{ Kelas Eksperimen I } & \multicolumn{2}{c}{ Kelas Eksperimen II } \\
\cline { 2 - 5 } & Frekuensi & Persentase (\%) & Frekuensi & Persentase (\%) \\
\hline Tinggi & 14 & 43,75 & 22 & 68,75 \\
Rendah & 18 & 56,25 & 10 & 31,25 \\
\hline Jumlah & 32 & 100,00 & 32 & 100,00 \\
\hline
\end{tabular}

Tabel 4. Rangkuman Hasil Uji Normalitas Prasyarat Analisis Prestasi Belajar

\begin{tabular}{lccc}
\hline \multicolumn{1}{c}{ Kelompok } & \multicolumn{2}{c}{ Keputusan Uji } \\
\cline { 2 - 4 } NHT dengan Modifikasi Tutor Sebaya & Kognitif & Afektif & Psikomotor \\
TSTS & Normal & Normal & Normal \\
MatematisTinggi & Normal & Normal & Tidak \\
MatematisRendah & Normal & Normal & Tidak \\
NHT dengan Modifikasi Tutor Sebaya pada & Normal & Normal & Normal \\
Matematis Tinggi & & & \\
NHT dengan Modifikasi Tutor Sebaya pada & Normal & Normal & Normal \\
Matematis Rendah & & & \\
TSTS pada Matematis Tinggi & Normal & Normal & Tidak \\
TSTS pada Matematis Rendah & Normal & Normal & Normal \\
\hline
\end{tabular}

Tabel 5. Rangkuman Hasil Uji Homogenitas Prasyarat Analisis Prestasi Belajar

\begin{tabular}{lccc}
\hline \multirow{2}{*}{ Kelompok } & \multicolumn{3}{c}{ Keputusan Uji } \\
\cline { 2 - 4 } & Kognitif & Afektif & Psikomotor \\
\hline NHT dengan Modifikasi Tutor Sebaya dan TSTS & Homogen & Homogen & Homogen \\
Matematis Tinggi dan Rendah & Homogen & Homogen & Homogen \\
Antarsel & Homogen & Homogen & Homogen \\
\hline
\end{tabular}

Tabel 6. Rangkuman Hasil Uji Hipotesis Prestasi Belajar Ranah Kognitif Siswa

\begin{tabular}{lcccc}
\hline \multicolumn{1}{c}{ Sumber } & Jenis Uji & Signifikansi (Sig.) & $\mathrm{A}$ & Keputusan \\
\hline Metode & & 0,002 & 0,050 & $\mathrm{H}_{\text {OA }}$ ditolak \\
$\begin{array}{l}\text { Pembelajaran } \\
\text { Kemampuan }\end{array}$ & Two-Way & & & \\
Matematis & ANOVA & 0,331 & 0,050 & $\mathrm{H}_{0 \mathrm{~B}}$ diterima \\
Interaksi & & 0,386 & 0,050 & $\mathrm{H}_{\text {OAB }}$ diterima \\
\hline
\end{tabular}


Tabel 7. Rangkuman Hasil Uji Hipotesis Prestasi Belajar Ranah Afektif Siswa

\begin{tabular}{lcccc}
\hline \multicolumn{1}{c}{ Sumber } & Jenis Uji & Signifikansi (Sig.) & $\alpha$ & Keputusan \\
\hline $\begin{array}{l}\text { Metodel } \\
\text { Pembelajaran }\end{array}$ & 0,963 & 0,050 & $\mathrm{H}_{0 \mathrm{~A}}$ diterima \\
$\begin{array}{l}\text { Kemampuan } \\
\text { matematis }\end{array}$ & ANO-Way & 0,691 & 0,050 & $\mathrm{H}_{0 \mathrm{~B}}$ diterima \\
Interaksi & & 0,015 & 0,050 & $\mathrm{H}_{0 \mathrm{AB}}$ ditolak \\
\hline
\end{tabular}

Tabel 8. Rangkuman Hasil Uji Hipotesis Prestasi Belajar Ranah Psikomotor Siswa

\begin{tabular}{lcccc}
\hline \multicolumn{1}{c}{ Sumber } & Jenis Uji & $\begin{array}{c}\text { Signifikansi (Sig.) } \\
\text { /(Asymp. Sig.) }\end{array}$ & $\alpha$ & Keputusan \\
\hline Metoe Pembelajaran & Kruskal- & 0,410 & 0,050 & $\mathrm{H}_{\mathrm{OA}}$ diterima \\
Kemampuan & Wallis & 0,945 & 0,050 & $\mathrm{H}_{\mathrm{OB}}$ diterima \\
Matematis & & 0,850 & 0,050 & $\mathrm{H}_{\mathrm{OAB}}$ diterima \\
Interaksi & & &
\end{tabular}

Pada uji hipotesis kedua, hasil uji untuk mengetahui pengaruh kemampuan Matematis terhadap prestasi belajar menunjukkan bahwa nilai Sig $(0,331)>a(0,05)$ untuk aspek kognitif, Sig. $(0,691)>\alpha(0,05)$ untuk aspek afektif, dan Asymp. Sig. $(0,945)>\alpha$ $(0,050)$ untuk aspek psikomotor. Karena signifikasi > a maka $\mathrm{H}_{0}$ diterima sehingga dapat disimpulkan bahwa tidak terdapat pengaruh kemampuan Matematis tinggi dan rendah terhadap prestasi belajar kognitif, afektif, dan psikomotor.

Pada hipotesis ketiga, hasil uji untuk mengetahui adanya interaksi antara metode pembelajaran terhadap kemampuan Matematis terhadap prestasi belajar menunjukkan nilai Sig. $(0,386)>\alpha(0,05)$ untuk aspek kognitif, Sig. $(0,015)<\alpha(0,05)$ untuk aspek afektif, dan Sig. $(0,850)>\alpha(0,05)$ untuk aspek psikomotor. Karena pada aspek kognitif dan psikomotor signifikasi $>\alpha$ maka $\mathrm{H}_{0}$ diterima sedangkan pada rana afektif signifikasi $<\alpha$ maka $\mathrm{H}_{0}$ ditolak sehingga dapat disimpulkan bahwa terdapat interaksi pembelajaran NHT disertai Tutor Sebaya dan TSTS dengan kemampuan matematis terhadap prestasi belajar afektif pada materi pokok Termokimia. tetapi tidak terdapat interaksi pembelajaran NHT disertai Tutor Sebaya dan TSTS dengan kemampuan matematis terhadap prestasi belajar ranah kognitif dan psikomotor pada materi pokok Termokimia.
Dari rangkuman Tabel 6 dapat diketahui bahwa hipotesis pertama ditolak. Hal ini berarti terdapat pengaruh metode pembelajaran NHT disertai Tutor Sebaya terhadap prestasi belajar kognitif siswa pada materi pokok Termokimia.. Dimana besarnya rata-rata nilai prestasi belajar ranah kognitif kelas eksperimen I adalah 70,13 sedangkan kelas eksperimen II adalah 63,8.

Kedua kelas eksperimen menggunakan model pembelajaran yang sama, yakni Cooperative learning. Yang membedakan adalah metode pembelajaran yang digunakan. Sehingga dalam pembahasan ini akan dijabarkan mengenai penggunaan Metode pembelajaran NHT disertai Tutor Sebaya dan TSTS terhadap hasil uji hipotesis prestasi belajar ranah kognitif.

Kedua metode pembelajaran tersebut sama-sama metode informal dari model pembelajan kooperatif. Keduanya memiliki karakter yang berbeda. NHT merupakan varian dari diskusi kelompok, namun siswa diberi penomoran di kepala masing-masing dengan tujuan mempermudah guru dalam menunjuk siswa untuk mempresentasikan pemecahan masalah dari salah satu soal dari seluruh persoalan yang dibebankan pada kelompok. Pemanggilan secara acak ini akan memastikan semua siswa benar-benar terlibat dalam diskusi.

Metode TSTS menekankan pada kegiatan belajar mengajar yang lebih 
aktif, karena pada metode ini siswa tidak hanya berdiskusi dengan kelompoknya namun juga dengan kelompok lain dalam 1 kelas. Siswa berperan sebajai tamu dan tuan rumah yang masing-masing bertukar satu sama lain tentang persoalan yang sedang dibahas. Metode TSTS juga memiliki kelemahan yaitu siswa harus berpindah tempat duduk saat bertamu dari kelompok satu menuju kelompok lain, sehingga hal ini menyita waktu lebih banyak.

Metode pembelajaran NHT cenderung lebih membosankan dibanding metode TSTS, maka dari itu perlu disertai dengan Tutor Sebaya. Hal tersebut membuat suasana diskusi menjadi lebih hidup, karena tutor bertugas untuk membantu teman satu tim untuk mencapai tujuan bersama yaitu memecahkan masalah yang diberikan guru. NHT disertai Tutor Sebaya menjadi lebih efisien dibandingkan dengan model pembelajaran TSTS karena NHT tidak banyak membuang waktu jika dibandingkan dengan TSTS, namun keaktifan kelas yang tercipta setara.

Penjelasan tersebut dapat mengarah pada suatu kesimpulan bahwa metode pembelajaran NHT disertai Tutor Sebaya lebih baik dalam hal menuntut siswa untuk lebih lama dalam memahami suatu materi pembelajaran dibanding metode pembelajaran TSTS. Berdasarkan alasan tersebut dapat disimpulkan bahwa metode pembelajaran NHT disertai Tutor Sebaya dan TSTS memiliki pengaruh terhadap prestasi belajar kognitif siswa. Hal ini didukung oleh penelitian Ambarwati, Haryono, Sukarjo [9] yang menyatakan metode pembelajaran NHT dilengkapi makromedia flash dapat meningkatkan prestasi belajar siswa.

Dari Tabel 7 pada uji hipotesis pertama dapat disimpulkan bahwa tidak terdapat pengaruh metode pembelajaran NHT disertai Tutor Sebaya dan TSTS terhadap prestasi belajar afektif siswa pada materi pokok Termokimia. Tidak adanya pengaruh metode pembelajaran terhadap prestasi belajar ranah afektif siswa karena prestasi belajar ranah afektif siswa lebih cenderung dipengaruhi oleh faktor internal siswa, seperti sikap, minat, konsep diri, nilai, dan moral. Sedangkan metode pembelajaran bukan merupakan faktor internal, melainkan eksternal sehingga pengaruhnya terhadap prestasi belajar ranah afektif tidak ada atau barangkali sangat kecil sehingga tidak begitu terlihat. Selain itu, untuk melihat perbedaan prestasi belajar ranah afektif siswa jelas tidak bisa dilakukan hanya dengan memberikan metode atau media pembelajaran dalam beberapa kali pertemuan saja karena perilaku afektif siswa terbentuk melalui proses yang membutuhkan waktu lebih lama dibanding aspek kognitif dan diperlukan dukungan dari lingkungan [3].

Tidak adanya pengaruh metode pembelajaran terhadap prestasi belajar afektif siswa menunjukkan bahwa prestasi belajar afektif dari kedua kelas adalah sama atau tidak ada yang lebih baik. Hal ini terjadi karena model yang digunakan oleh kedua kelas sama dan metode yang digunakan juga merupakan metode yang tidak begitu memiliki banyak perbedaan sehingga sikap yang ditunjukkan siswa terhadap pembelajaran oleh kedua kelas cenderung sama.

Dari Tabel 8, pada hipotesis pertama dapat diketahui bahwa tidak terdapat pengaruh metode pembelajaran NHT disertai Tutor Sebaya dan TSTS terhadap prestasi belajar psikomotor siswa pada materi pokok Termokimia. Ranah psikomotor dalam penelitian ini dinilai dari keterampilan atau kemampuan bertindak siswa ketika praktikum di laboratorium. Tidak terdapatnya perbedaan dari kedua kelas eksperimen menunjukkan bahwa keterampilan rata-rata yang dimiliki oleh siswa sama. Menurut Sudijono [10], prestasi belajar psikomotor merupakan kelanjutan dari prestasi belajar kognitif dan afektif yang diimplementasikan dalam bentuk perilaku atau perbuatan sesuai dengan makna yang terkandung dalam ranah kognitif dan afektif. Apabila model dan media pembelajaran tidak memberikan pengaruh signifikan prestasi belajar kognitif dan afektif, kemungkinan besar juga tidak memberikan pengaruh signifikan pada psikomotor. 
Di samping itu, prestasi belajar psikomotor hakikatnya merupakan manifestasi dari gerakan (hands on activity). Dalam taksonomi prestasi belajar psikomotor yang berasal dari Simpson [11], gerakan yang dimaksud salah satunya adalah gerakan terbiasa (mechanism). Kemampuan ini dimiliki oleh siswa karena latihan berulang-ulang sehingga keberadaan model dan media pembelajaran yang digunakan dalam penelitian tidak bisa mengubah atau mempengaruhi kemampuan terse-but dalam waktu singkat.

Pada hipotesis kedua dari Tabel 6, tidak adanya pengaruh kemampuan Matematis terhadap prestasi belajar kognitif karena kemampuan matematis yang digunakan oleh siswa di dalam penyelesaian persoalan materi Termokimia hanya cenderung pada controlling variables (pengontrolan variabel) sedangkan metode penilaan yang digunakan untuk menunjukkan tinggi rendahnya kemampuan matematis siswa mencakup beberapa metode operasi mamatika. Sehingga dapat disimpulkan bahwa kemampuan matematis tidak begitu berpengaruh terhadap prestasi belajar siswa.. Hasil yang sama juga diperoleh untuk prestasi belajar afektif pada hipotesis kedua (Tabel 7). Tidak adanya pengaruh kemampuan Matematis terhadap prestasi belajar afektif karena Kemampuan matematis berhubungan dengan kemampuan menyelesaikan suatu persoalan dalam operasi perhitungan sedangkan ranah afektif berkaitan dengan sikap dan nilai. Dari kedua definisi ini tampak bahwa kemampuan Matematis tidak berhubungan dengan ranah afektif. Hasil uji hipotesis kedua prestasi belajar ranah psikomotor juga sama dengan kognitif dan afektif (Tabel 8). Tidak terdapatnya pengaruh kemampuan Matematis terhadap prestasi belajar psikomotor karena prestasi belajar ranah psikomotor diukur dari kemampuan bertindak siswa. Sementara untuk melakukan aspek motorik tersebut siswa dengan kemampuan Matematis tinggi dan rendah cenderung sama kemampuannya. Hal ini karena kemampuan Matematis lebih cenderung berada pada struktur kognitif siswa dibanding dalam psikomotor sehingga hubungannya tidak begitu erat. Melalui Tabel 6, dan 8 pada hipotesis ketiga diketahui bahwa tidak terdapat interaksi antara metode pembelajaran dengan kemampuan Matematis terhadap prestasi belajar kognitif dan psikomotor siswa. Tidak terdapatnya interaksi terhadap prestasi belajar kognitif karena Siswa yang menerima pembelajaran dengan metode pembelajaran NHT disertai Tutor Sebaya cenderung memeroleh prestasi belajar ranah kognitif lebih baik dibanding dengan siswa yang berada di kelas dengan metode pembelajaran TSTS tanpa melihat kemampuan matematis siswa. Tidak adanya interaksi antara metode dan media yang digunakan dengan kemampuan matematis siswa terhadap prestasi belajar ranah psikomotor berarti tidak terdapat kelompok yang paling menonjol rata-rata prestasi belajar psikomotornya. Siswa yang menerima pelajaran dengan metode pembelajaran TSTS memiliki prestasi belajar psikomotor cenderung lebih baik dibanding kelas yang menggunakan metode NHT tanpa perlu melihat kemampuan matematis yang dimiliki siswa.

Tabel 7 pada hipotesis ketiga menunjukkan bahwa terdapat interaksi metode pembelajaran NHT disertai Tutor Sebaya dan TSTS dengan kemampuan matematis terhadap prestasi belajar afektif siswa pada materi pokok Termokimia. Adanya interaksi antara metode yang digunakan dengan kemampuan matematis siswa terhadap prestasi belajar ranah afektif berarti terdapat kelompok yang paling menonjol rata-rata prestasi belajar afektifnya.

\section{KESIMPULAN}

Berdasarkan hasil penelitian yang telah dilakukan dapat disimpulkan bahwa: (1) Terdapat pengaruh pembelajaran NHT disertai Tutor Sebaya dan TSTS terhadap prestasi belajar kognitif, tetapi tidak terdapat pengaruh pembelajaran terhadap prestasi belajar ranah afektif dan psikomotor pada materi pokok Termokimia. Berdasarkan rata- 
rata nilai prestasi belajar ranah kognitif, siswa yang menerim pembelajaran NHT disertai Tutor Sebaya $(70,13)$ menghasilkan prestasi belajar kognitif yang lebih baik daripada siswa yang menerima pembelajaran TSTS $(63,75)$.; (2) Tidak terdapat pengaruh kemampuan matematis tinggi dan rendah terhadap prestasi belajar ranah kognitif, afektif, dan psikomotor pada materi pokok Termokimia; dan (3) Terdapat interaksi pembelajaran NHT disertai Tutor Sebaya dan TSTS dengan kemampuan matematis terhadap prestasi belajar afektif pada materi pokok Termokimia. tetapi tidak terdapat interaksi pembelajaran NHT disertai Tutor Sebaya dan TSTS dengan kemampuan matematis terhadap prestasi belajar ranah kognitif dan psikomotor pada materi pokok Termokimia.

\section{UCAPAN TERIMA KASIH}

Bapak Paerah, S.Pd., selaku guru mata pelajaran kimia Kelas XI IPA SMA Negeri 3 Boyolali yang telah mengijinkan peneliti mengguna-kan kelasnya untuk penelitian.

\section{DAFTAR RUJUKAN}

[1] Slameto. 2003. Belajar dan Faktor - Faktor Yang Memengaruhinya. Jakarta: Rineka Cipta

[2] Peraturan Menteri Pendidikan dan Kebudayaan. (2014). Peraturan Menteri Pendidikan dan Kebudayaan Republik Indonesia Nomor 160 Tahun 2014 Tentang Pemberlakuan Kurikulum Tahun 2006 dan Kurikulum 2013. Menteri Pendidikan dan Kebudayaan Republik Indonesia

[3] Kemendikbud. (2014). Pengembangan KTSP di SMA Tahun 2014. Direktorat Jenderal Pendidikan Menengah dan Direktorat Pembinaan Sekolah Menengah Atas.
[4] Huda, Miftahul. 2013. Cooperative Learning Metode, Teknik, Struktur, dan Model Pembelajaran. Yogyakarta : Pustaka pelajar

[5] Manurung, Irene Widyastuti., Bakti Mulyani., Sulistyo Saputro. 2013. Jurnal Pendidikan Kimia. 2(4): 2531

[6] Depaz, I., dan Moni, R.W. 2008. Bioscience Education Journal. 11, 98-108.

[7] Sanubari, F., Yamtinah, S., \& Rejedki, T. (2014). Jurnal Pendidikan Kimia (JPK). 3(4):145154

[8] Fitriyah, N., Purwantoyo, E. Chasnah 2012. Unnes Jurnal of Biology Education. 1(2): 32-37

[9] Ambarwati, T., Haryono, Sukarjo. 2014..Jurnal Pendidikan Kimia. 3(1): 58-64

[10] Sudijono, A. (2008). Pengantar Evaluasi Pendidikan. Jakarta: PT Raja Grafindo Persada

[11] Purwanto. (2014). Evaluasi Hasil Belajar. Yogyakarta: Pustaka Pelajar 